\title{
水田上の仮設道路を目的とした パレスシート工法の実証試験
}

後藤順一 $1 \cdot$ 三浦一男 $2 \cdot$ 柴田健一 $3 \cdot$ 抦㠃和孝 $4 \cdot$ 河合徹夫 $5 \cdot$ 北本幸義 $6 \cdot$ 吉田輝 7

\begin{abstract}
パレスシート工法 ${ }^{1) ~ 331}$ は，軟弱地盤上においてシートを格子状に組み合わせたジャケットに固定し，ジャケ ット内に流動化固化剤を注入し補強枠を形成する工法で, 固化後の補強染が有する曲げ抵抗により、重機が走 行した場合の覆土圧の局所的な偏りを防ぐものである.

今回, 地震に伴うがけ崩れで通行不可能になった道路の緊急迁回路や資材運搬用の仮設道路を想定し, 既存 の休耕田上にパレスシート工法を適用する実証実験を行った. 休耕田の軟弱な地盤上にパレスシートを敷設し 重量 $120 \mathrm{kN}$ の重機を反復走行させた結果, 安定走行できることが確認でき, 軟弱地盤上に仮設道路を施工する 場合にパレスシート工法の有効性が高いことが実証された。
\end{abstract}

キーワード : 袋, ジャケット, 軟弱地盤, 不等沈下, 仮説道路

\section{1.はじめに}

パレスとは,「 Padding lattice reinforcement」の 略であり, Palace に含まれている宮殿や王宮という意 味合いの碁盤の目に形成される街並みが，本工法の出来 型と似ていることも, 名称の別の要素となっている. 従 来, 軟弱地盤を改良する工法の一つとして, 布または樹 脂製の土木シート等のジオテキスタイルを敷いてから良 質土で覆う表層処理が行われている. しかし，ジオテキ スタイルの曲げ岡性が小さいため, 覆土や施工機械の重 みによって局所的に過大な張力が発生し, シートが破断 して，その周辺の軟弱地盤が大きく変状度々生じている。 そのため，セメントなどによる固化処理や竹組みなどを 併用する場合 ${ }^{4)}$ もあるが、施工性の改善、工期短縮が課 題となっている.

筆者らは，軟弱地盤状においてシートを，消防ホー スのような筒状の織物（以下，ジャケット）を格子状に 組み合わせた格子状ジャケットに固定して，さらにジャ ケット内にモルタルを注入することで, 格子状のモル夕 ル枠を形成してシートに剛性を持たせる本工法を開発し た.

\section{2. 実証実験の概要}

\section{（1）実験目的}

例えば，水田の奥地に発生した斜面崩壊等の災害を 復旧する場合，水田上を重機および資材搬送車等が走行 する必要がある. その場合、従来は水田に砕石を投入し 敷鉄板を敷設してトラフィカビリティを確保した後，工 事を行う. その場合に工事完了後現状復帰を行う必要が あるが, このとき, 水田上の砕石を完全に取り除くのは 困難であった。このような場合に，敷設も撤去も容易な パレスシートを使用した工法が適していると考え，長野 県豊丘村において天竜川沿いの休耕田を利用し，施工性 確認試験および重機による安定走行確認試験を実施し検 証を行った.

\section{（2）実験場所および工程}

実証実験は，長野県下伊那郡豊丘村大字河野 7803 （図-1）の休耕田で行った. 施工期間は平成 17 年 7 月 〜11月で，7月にパレスシート敷設からモルタル注入ま での施工性確認試験，9月に重機の繰り返し走行による 安定走行確認試験を行った。 また最後に施工性確認試験 の一環として 11 月にパレスシートの撤去を行った. な お、施工面積は $24 \mathrm{~m} \times 18 \mathrm{~m}$ の領域で行った,

\footnotetext{
1正会員, 芦森工業株式会社 ジオビジネスユニット（テ566-0001 大阪府揸津市千里丘7-11-61）

2正会員, 長豊建設株式会社＼cjkstart環境部（广935-0001 長野県飯田市座光寺5558番地1）

3正会員, 芦森工業株式会社 ジオビジネスユニット（テ566-0001大阪府摂津市千里丘7-11-61）

4非会員, 芦森工業株式会社 ジオビジネスユニット（テ566-0001大阪府摄津市千里丘7-11-61）

5非会員, 芦森工業株式会社 機能製品品質保証部（广566-0001 大阪府搑津市千里丘7-11-61）

6正会員, 鹿島建設株式会社 技術研究所（广182-0036 東京都調布市飛田給2-19-1）

7正会員，鹿島建設株式会社 技術研究所（テ $182-0036$ 東京都調布市飛田給2-19-1）
} 


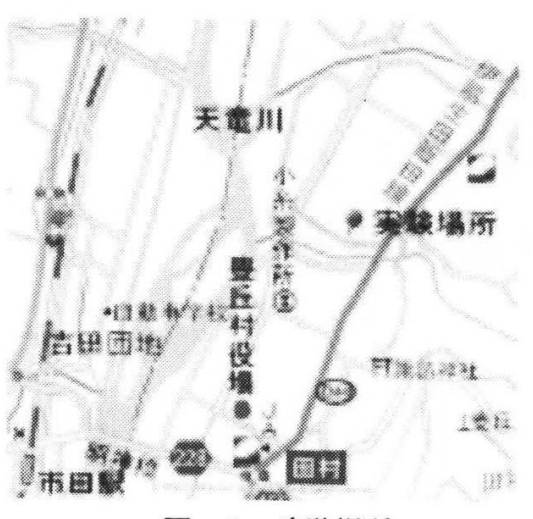

図-1 実験場所

\section{3. 実証実験に使用した材料}

本実験で使用した格子状ジャケットは $2 \mathrm{~m}$ ピッチの格 子で, $24 \mathrm{~m} \times 18 \mathrm{~m}$ の領域に敷設した. 表- 1 に本実験に 用いたシートと補強材の材料特性を示す。

表ー 1 シート及び格子状ジャケットの材料特性

\begin{tabular}{|c|c|c|}
\hline \multicolumn{2}{|l|}{ シート } & $\begin{array}{l}\text { 材質 } \mathrm{PE} \\
\text { 引張り強さ } 11 \mathrm{kN} / \mathrm{m} \\
\text { 伸度 } 24 \% \\
\text { 厚さ } 0.3 \mathrm{~mm}\end{array}$ \\
\hline \multirow{2}{*}{ 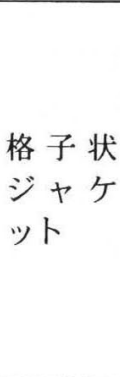 } & $\begin{array}{l}\text { ジャケッ } \\
\text { ト }\end{array}$ & $\begin{array}{l}\text { 材質 ポリエステル織布 } \\
\text { 直径 } 100 \mathrm{~mm} \\
\text { 経方向の引張り強さ } 714 \mathrm{kN} / \mathrm{m} \\
\text { 経方向の破断伸度 } 20 \%\end{array}$ \\
\hline & 固化剤 & $\begin{array}{l}\text { 材質 モルタル＋流動化材＋水中不分 } \\
\text { 離材 } \\
\text { 強度（材令 } 2 \text { 日）圧縮強度 } 22,000 \mathrm{kN} / \mathrm{m}^{2} \\
\text { スランプフロー（日本道路公団規格） } \\
\text { 250mm〜350mm }\end{array}$ \\
\hline
\end{tabular}

\section{4. 実証実験}

\section{（1）実証実験の流れ}

パレスシート工法の施工は, 大きく分けてパレスシー 卜の敷設, モルタル注入の 2 つの程から成り，撤去が 必要な場合にはパレスシート撤去工程が入る. 今回の実 証実験では，これらの施工性を確認するとともに，パレ スシート撤去の前にトラフィカビリティ試験を行い, 安 定走行性を確認した.

\section{（2）パレスシート敷設工程}

写真－1 の軟弱地盤の水田上にシートを設置し，そ の上に写真－20ように格子状ジャケットを展開した. 敷設は人力のみで行い，約 1.5 時間で行うことができた。 尚、施工前の表層部付近の地盤状況は $\mathrm{N}$ 值 $=1.4$ の軟弱 地盤であった。

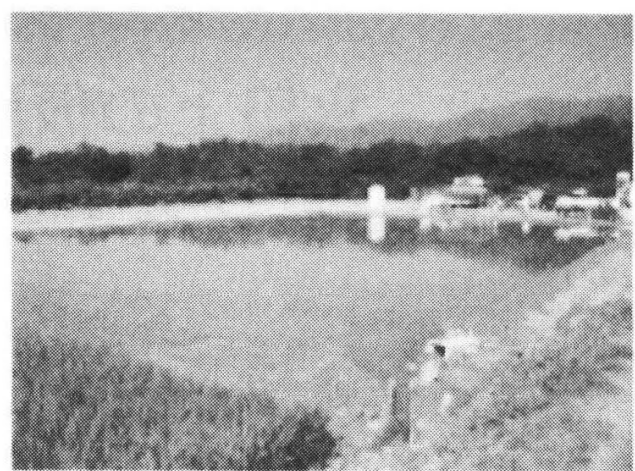

写真－ 1 施工前の水田

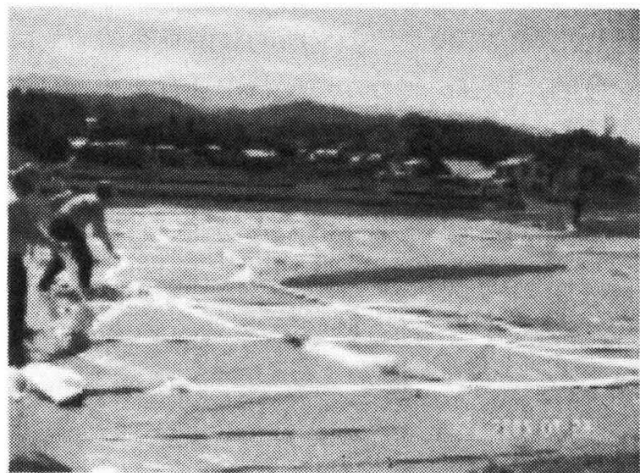

写真ー 2 ジャケット展開中

\section{（3）モルタル注入工程}

ミキサー車でモルタルを現地まで運搬し，現地にて 流動化材と水中不分離材をミキサ一車内へ投入し，5 分 間強制摚拌した. 水中不分離材は, 固化剂中の水分がジ ヤケット表面から逸脱して固化剂の流動性が低下する事 を押さえる役割を果たしており、そのため長距離圧送が 可能となっている.

次にミキサー車内の固化剤をホッパーで受け, スク イーズ式のモルタルポンプで格子状ジャケット内に固化 剤を注入した. 注入は約 $35 \mathrm{~L} / \mathrm{min}$ の速度で行い, トータ ル $4 \mathrm{~m}^{3}$ の固化剂を約 2 時間で注入した. 注入機材の洗浄 水はミキサー車内に返すことで産業廃棄物を出すことな く施工は完了した. 表一 2 に注入に使用した機材を, 写 真一 $3 、 4$ に注入中の写真を示す.

表ー2 注入工程で使用した機材一覧

\begin{tabular}{|l|l|}
\hline 機材 & 数量 \\
\hline ミキサー車 & 1 \\
\hline ホッパー 290L & 1 \\
\hline モルタルホホンプ 最大 100L/min & 1 \\
\hline 発電機 200V/100V & 1 \\
\hline 洗浄車 30kN & 1 \\
\hline 圧力計 & 2 \\
\hline 流量計 & 1 \\
\hline データ収集装置 & 1 \\
\hline パソコン & 1 \\
\hline パソコン発電機 100V & 1 \\
\hline
\end{tabular}




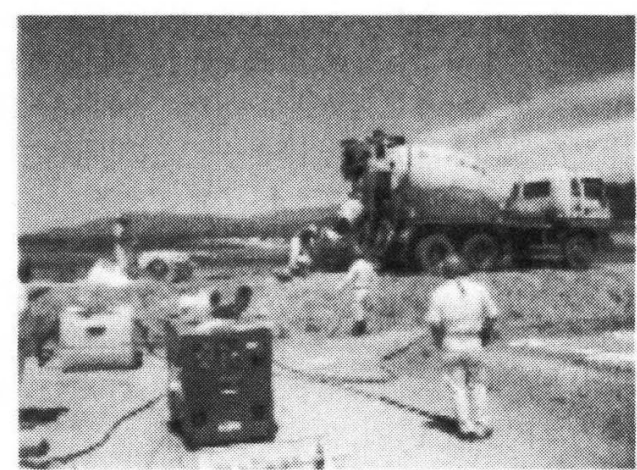

写真 -3 注入中の様子

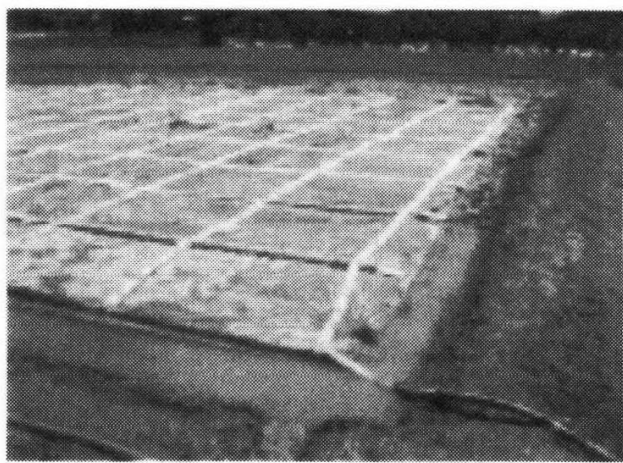

写真－4 格子ジャケットへの注入状況

（4）トラフィカビリティ試験

格子状ジャケットの交差部に図ー2のように敷鉄板 を配置し，その上を写真－5のように重量 $120 \mathrm{kN}$ のバッ クホウを 12 回繰り返して走行させたが, 水田に変状は 発生せず安定走行できることが確認できた．なお，敷鉄 板は $\mathrm{t}=25 \mathrm{~mm} \times 1524 \mathrm{~mm} \times 3048 \mathrm{~mm}$ のものを 29 枚使用した.

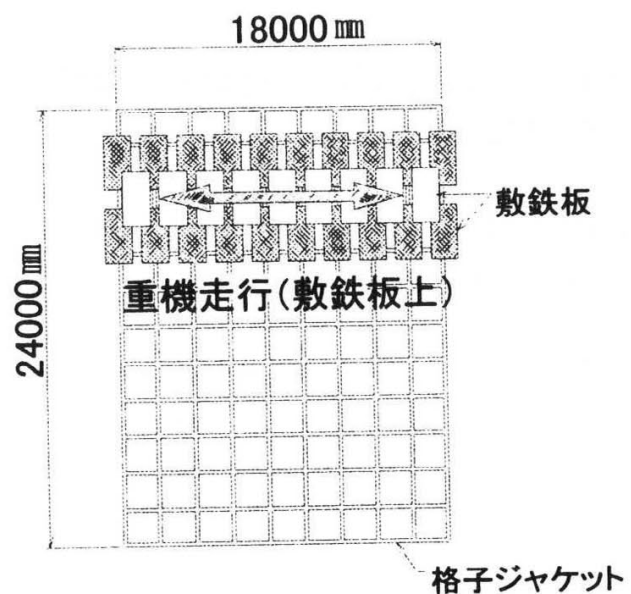

図-2 敷鉄板の配置状況

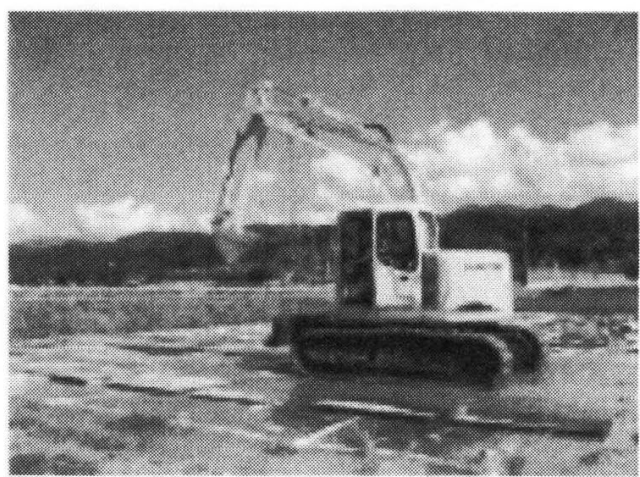

写真－5 重機による走行試験

\section{（5）パレスシート撤去工程}

パレスシートの撤去は, 解体フォークと鉄骨カッタ 一をそれぞれ装着した 2 台の小旋回ショベルを使用して 格子状ジャケットを短く切断していき, その後切断した ジャケットを産業廃棄物引き取り業者のトラックに積み 込む方法を選定した. 約 $400 \mathrm{~m}^{2}$ のパレスシートは 1 日で 完全に撤去することができた。 また、シート撤去後には、 写真－8のように格子ジャケット部以外の地盤からは植 物が生えてきており，元の地盤環境を壊さない工法であ ることも確認できた。

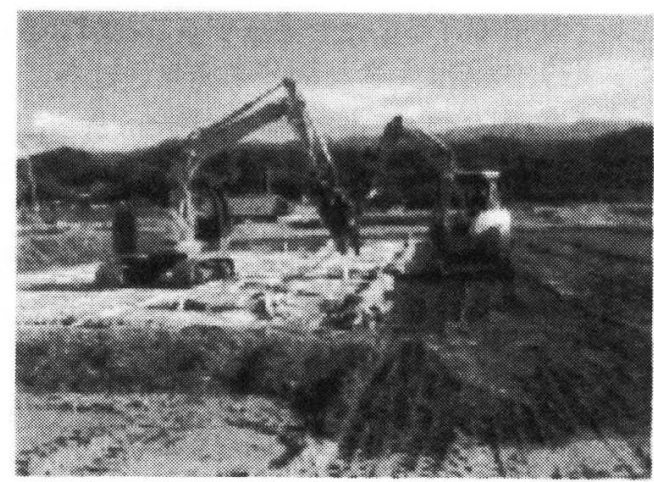

写真一 6 格子状ジャケットの解体 (切断)

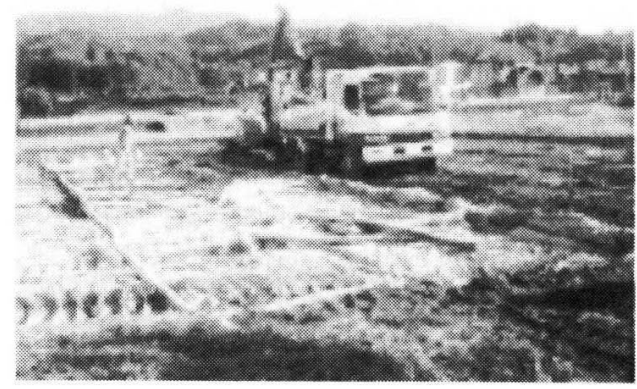

写真ー 7 解体したジャケットの積み込み 


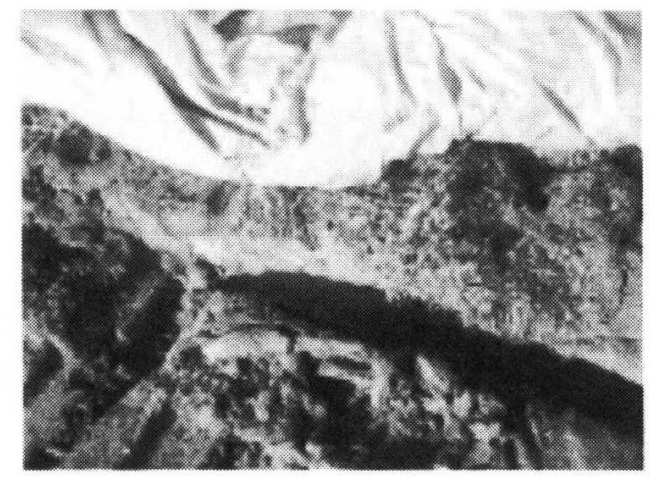

写真－8 パレスシート撤去後の地盤

\section{5. おわりに}

水田上におけるパレスシートの施工は，重機を使用 する必要なく, $2 \mathrm{t}$ トラック 1 台で搬入できる程度の機 材で施丁できることが確認できた. さらに，水田を污す ことなく, また, 産業廃棄物も発生させることなく施工 することができた.

このように, 水田のような軟弱地盤上でも本工法を 用いれば，砕石を投入したり地盤を固化処理したりする こと無く，重機が安定走行できることが確認でき，災害 復旧時に，本工法で対策すれば水田等の軟弱地盤を仮設 道路として使用できることを実証することができた。

また，撤去作業は大きな騒音を発生させることなく， しかも少人数で行えることが確認できた. さらに、撤去 後地盤から植物が生えていたことより，施工前の地盤環 境が保護されていることが確認できた.

これにより, 水田等の地盤環境の保護が必要な軟弱 地盤を補強する工法としてパレスシート工法が有効であ

\section{ることが証明された。}

今回の実験では, $\mathrm{N}$ 值 $=1.4$ 程度の軟弱地盤上でも,

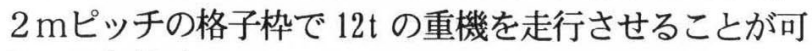
能な地盤補強ができることがわかった. 今後は水田上に 限らず様々な地盤条件と格子枠ピッチとの関係について 調査を行いデー夕を蓄積していく予定である.

謝辞 : 本実験を行うにあたり協力していただいた芦森工 業株式会社パルテムジオカンパニーの部員一同, 施工に 協力していただいた鹿島建設株式会社および長豊建設株 式会社の方々に謝意を表します.

\section{参考文献}

1）北本幸義・吉田輝他：筒状織物やホース状材料等 （ジャケット）の地盤工学分野への適用について, ジオシンセティック論文集, Vol.18, pp. 225230, 2003. 12

2）吉田幸義・北本輝他 : 格子状補強枠を有するシート 工法の表層処理効果, 第 40 回地盤工学研究発表会, pp. 1941-1942, 2005. 7

3）嶋田義人・北本幸義他 : 格子状補強枠を有するシ一 卜工法の沈下抑制効果の評価, 土木学会第 60 回年次 学術講演会, pp. 225-230, 2005, 9

4）社団法人地盤工学会 超軟弱粘土地盤に対する調 查・地盤改良工法に関する研究委員会：「粘土地盤 における最新の研究と実際」一微視的構造の観察か ら超軟弱地盤対策技術までーに関するシンポジウム, 第 2 巻, PP358-362, 2002. 5

\title{
PROOF EXPERIMENT ON TEMPORARY ACCES CONSTRUCTED ON RICE FIELD USING PALACE SHEET
}

\author{
Junichi GOTOU, Kazuo MIURA, Kenichi SHIBATA, Kazutaka KARASAKI, \\ Tetsuo KAWAI, Yukiyoshi KITAMOTO and Teru YOSHIDA
}

\footnotetext{
The Palace seat industrial method is a soft subsoil reinforcement industrial method with which the reinforcement frame is formed by injecting mortar into a lattice jacket that integrated with the engineering works seat.

This time, the proof experiment that constructed the temporary road of materials vehicular on the rice field using palace sheet was done. $120 \mathrm{kN}$ in weight heavy equipment ran with stability on the road that had been constructed on the soft subsoil using palace sheet.

It was able to be proven to be able to use the rice field as a temporary road of urgent disaster if it constructed it by this method.
} 